\title{
Cell type of origin as well as genetic alterations contribute to breast cancer phenotypes
}

\author{
Divya Bhagirath ${ }^{1, *}$, Xiangshan Zhao ${ }^{1, *}$, William W. West ${ }^{2,7}$, Fang Qiu ${ }^{3}$, \\ Hamid Band ${ }^{1,2,4,5,6,7}$, Vimla Band ${ }^{1,7}$ \\ ${ }^{1}$ Department of Genetics, Cell Biology and Anatomy, College of Medicine, University of Nebraska Medical Center, Omaha, NE \\ 68198, USA \\ ${ }^{2}$ Departments of Pathology and Microbiology, College of Medicine, University of Nebraska Medical Center, Omaha, NE 68198, \\ USA \\ ${ }^{3}$ Department of Biostatistics, College of Public Health, University of Nebraska Medical Center, Omaha, NE 68198, USA \\ ${ }^{4}$ Biochemistry and Molecular Biology, College of Medicine, University of Nebraska Medical Center, Omaha, NE 68198, USA \\ ${ }^{5}$ Pharmacology and Experimental Neuroscience, College of Medicine, University of Nebraska Medical Center, Omaha, NE \\ 68198, USA \\ ${ }^{6}$ Eppley Institute for Cancer and Allied Diseases, University of Nebraska Medical Center, Omaha, NE 68198, USA \\ ${ }^{7}$ Fred and Pamela Buffett Cancer Center, University of Nebraska Medical Center, Omaha, NE 68198, USA \\ *These authors have contributed equally to this work
}

Correspondence to:

Vimla Band, e-mail: vband@unmc.edu

Keywords: transformation, stem cells, xenograft, breast cancer, metastasis

Received: November 02, $2014 \quad$ Accepted: April 10,2015 Published: April 22, 2015

\section{ABSTRACT}

Breast cancer is classified into different subtypes that are associated with different patient survival outcomes, underscoring the importance of understanding the role of precursor cell and genetic alterations in determining tumor subtypes. In this study, we evaluated the oncogenic phenotype of two distinct mammary stem/ progenitor cell types designated as $\mathrm{K5}^{+} / \mathrm{K19}^{-}$or $\mathrm{K}^{+} / \mathrm{K19}^{+}$upon introduction of identical combinations of oncogenes-mutant H-Ras (mRas) and mutant p53 (mp53), together with either wild-type ErbB2(wtErbB2) or wild-type EGFR (wtEGFR). We examined their tumor forming and metastasis potential, using both in-vitro and invivo assays. Both the combinations efficiently transformed $\mathrm{K}^{+} /{\mathrm{K} 19^{-}}^{-}$or $\mathrm{K5}^{+} / \mathrm{K19}^{+}$ cells. Xenograft tumors formed by these cells were histologically heterogeneous, with variable proportions of luminal, basal-like and claudin-low type components depending on the cell types and oncogene combinations. Notably, $\mathrm{K5}^{+} / \mathrm{K19}^{-}$cells transformed with mRas/mp53/wtEGFR combination had a significantly longer latency for primary tumor development than other cell lines but more lung metastasis incidence than same cells expressing $\mathrm{mRas} / \mathrm{mp53} / \mathrm{wtErbB2} \mathrm{K5}^{+} /{\mathrm{K} 19^{+}}^{+}$cells exhibit shorter overall tumor latency, and high metastatic potential than $\mathrm{K}^{+} / \mathrm{K19}^{-}$cells, suggesting that these $\mathrm{K19}^{+}$progenitors are more susceptible to oncogenesis and metastasis. Our results suggest that both genetic alterations and cell type of origin contribute to oncogenic phenotype of breast tumors.

\section{INTRODUCTION}

Breast cancer is the second leading cause of cancer related deaths among women [1]. Molecular profiling of patient-derived tumors has revealed different subtypes based on gene expression signatures. The understanding of origin of various subtypes is highly important area of research considering that distinct subgroups result in significantly different outcomes, with the basal-like subtype correlating with the worst outcome, followed by claudin-low, ErbB2 over-expressing, luminal-B, normal-like and luminal-A subtype $[2,3]$. The nature of genetic alterations affecting the cell may therefore play an important role in determining the pathology (i.e. latency, incidence etc.) of resulting tumors. Another important factor is the cell of origin in which the initiating oncogenic 
event takes place. The characteristic nature of a particular cell may determine its susceptibility towards oncogenic transformation as well as its ability to develop to primary and metastatic tumors.

To understand the importance of cell type in determining tumor phenotype, in previous study investigators isolated two distinct human mammary epithelial cells (hMECs) by culturing normal mammary tissue under different conditions, transformed the cells with an identical set of oncogenes and injected these into mammary glands of immunocompromised mice. The injected cell lines gave rise to distinct tumors depending upon their differentiation states and developed lung metastasis in a cell type dependent manner [4]. Similarly, another team of investigators showed that the origin of the transformed cell can determine the formation of tumor subtypes [5]. Both studies support the idea that breast tumor subtypes may represent malignancies of biologically distinct cell types producing distinct disease entities. However, it is still not known whether the intrinsic differences in cell lines (susceptibility to transformation) may regulate the tumor phenotype by itself or their oncogenic behaviors (transformation ability, tumor onset, incidence and metastatic capability) are also governed by the nature of genetic insults inflicted upon them. Here, we addressed these questions by subjecting two human mammary epithelial cell lines that exhibit defined differences but are cultured under identical conditions to transformation with defined oncogene combinations. Clonal cell lines corresponding to human mammary stem/progenitor cell types were previously isolated from a single healthy reduction mammoplasty specimen and immortalized using the catalytic subunit of human telomerase (hTERT). These two types of cell lines are designated as $\mathrm{K} 5^{+} / \mathrm{K} 19^{-}$or $\mathrm{K} 5^{+} / \mathrm{K} 19^{+}$based on cytokeratin $(\mathrm{K})$ expression defining different lineage (Microarray accession no. GSE22580). Both of these cell types exhibit self-renewal and differentiate into both luminal and myoepithelial cells in vitro in defined medium [6, 7]. Majority of breast cancers are carcinomas and K19 positive [8, 9]. Expression of K19 can be used as prognostic marker for breast cancer [10] and presence of $\mathrm{K} 19^{+}$circulating tumor cells (CTCs) in patients before or after treatment is associated with poor disease free survival [11-13]. However, K19 positive normal mammary epithelial cells are difficult to isolate and immortalize in culture. Thus, availability of $\mathrm{K}^{+} / \mathrm{K} 19^{+}$and $\mathrm{K} 5^{+} / \mathrm{K} 19^{-}$ mammary stem/progenitor cell lines generated in our laboratory provides a unique opportunity to assess their ability to serve as cells of origin for breast tumors and the impact of cell type versus oncogenes in tumor associated characteristics. Transformation of these two cell lines with different oncogene combinations was followed by extensive in vitro and in vivo analyses to demonstrate that both nature of cell type and genetic alterations contribute to the primary and metastatic behavior of tumors resulting from these cells.

\section{RESULTS}

\section{In vitro oncogenic transformation of $\mathrm{K5}^{+} / \mathrm{K} 19^{-}$or $\mathrm{K5}^{+} / \mathrm{K}^{1} 9^{+}$cells}

We have previously isolated and characterized two types of hTERT-immortalized mammary epithelial stem/ progenitor cells that are designated as $\mathrm{K} 5^{+} / \mathrm{K} 19^{-}$or $\mathrm{K}^{+} /$ $\mathrm{K}_{19}{ }^{+}$based on keratin expression (Microarray accession no. GSE22580, Supplementary Table 1) [6]. We have reported previously that $100 \%$ of cells in these cell lines express designated keratins. These cell lines maintain self-renewal and are able to differentiate into both luminal and myoepithelial lineages upon culturing in defined medium [6]. We introduced mRas, mp53 along with either wtErbB2 or wtEGFR in both cell types using retroviral/ lentiviral infection. The choice of mp53, wtEGFR and wtErbB2 as transforming genes was based on their wide use in the literature and their well-known occurrence in breast tumors $[4,5,14-18] . \mathrm{K} 5^{+} / \mathrm{K} 9^{-}$and $\mathrm{K}^{+} / \mathrm{K} 19^{+}$ cells with empty vectors were used as controls in these experiments. As a first step, over-expression of various introduced genes was confirmed using western blotting (Figure 1A).

To analyze the transforming ability of exogenously introduced oncogenes and to determine susceptibility of these two cell lines to oncogene induced transformation, we performed in vitro soft agar assays and assessed the ability of oncogene-transduced cell lines to proliferate in an anchorage independent manner. As expected, cells expressing vectors alone failed to exhibit anchorage independent growth. $\mathrm{K}^{+} / \mathrm{K} 19^{-}$and $\mathrm{K}^{+} / \mathrm{K} 19^{+}$cells expressing mRas/mp53 together with either wtErbB2 or wtEGFR showed anchorage independent growth (Figure 1B, 1C). Notably, total number of colonies in $\mathrm{K}^{+} /$ $\mathrm{K} 19^{+}$cells, were significantly higher than that of colonies obtained by transformed $\mathrm{K}^{+} / \mathrm{K} 19^{-}$cells (Figure 1B). These results demonstrate that in vitro transformation ability of a cell type is dependent on intrinsic differences within the cell lines but not the oncogene combination over-expressed by the cells. 
A

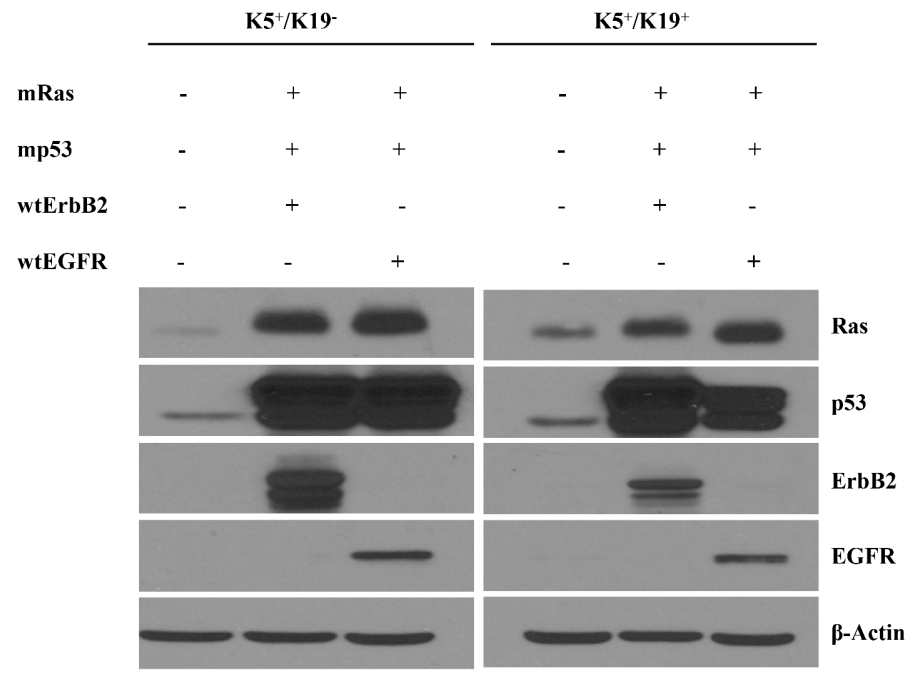

B
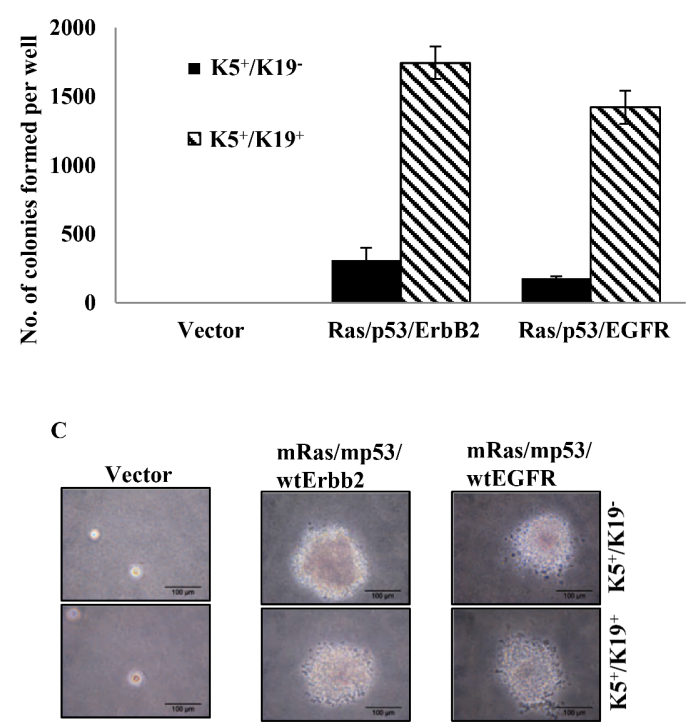

Figure 1: Transformation of $\mathrm{K5}^{+} / \mathrm{K} 19^{-}$or $\mathrm{K5}^{+} / \mathrm{K} 19^{+}$cells with different gene combination. (A) $\mathrm{K} 5^{+} / \mathrm{K} 19^{-}$or $\mathrm{K} 5^{+} / \mathrm{K} 19^{+}$cell lines over-expressing mutant p53, mutant Ras, wild type ErbB2 and wild type EGFR in triple oncogene combinations were analyzed by Western Blotting. $\beta$-Actin was used as loading control. (B) Anchorage independent growth assay of $\mathrm{K} 5^{+} / \mathrm{K} 19^{-}$and $\mathrm{K} 5^{+} / \mathrm{K} 19^{+}$cells with vector or triple gene combinations. Mean \pm S.D of a representative experiment done in triplicate is shown. Three independent experiments were done. (C) Representative images (magnification $40 \mathrm{X}$ ) of colonies from $\mathrm{K} 5^{+} / \mathrm{K} 19^{-}$and $\mathrm{K} 5^{+} / \mathrm{K} 19^{+}$cells with vector or triple oncogene combination are shown here.

\section{Transformation of $\mathrm{K5}^{+} /{\mathrm{K} 19^{-}}^{-}$or $\mathrm{K5}^{+} / \mathrm{K} 19^{+}$cells leads to enrichment of stem cell population, and reduction in the proportion of differentiated cells}

It has been shown that loss of function of the tumor suppressor p53 enhances self-renewal ability of mammary stem cells [19]. Similarly, other studies have shown that EGFR [20, 21], ErbB2 [22] or Ras [23, 24] play an important role in mammary stem cell self-renewal. We have previously shown that upon immortalization (preneoplastic transformation) with certain oncogenes, the stem/progenitor cell lines lose their ability to differentiate into myoepithelial cells [25]. Therefore, in this study we evaluated the impact of triple oncogene combinations on stem cell self-renewal and differentiation. We have previously shown that $\mathrm{K} 5^{+} / \mathrm{K} 19^{-}$and $\mathrm{K} 5^{+} / \mathrm{K} 19^{+}$mammary stem/progenitor cell lines are bi-potent stem/uncommitted progenitors and are able to differentiate into both luminal and myoepithelial cells under appropriate differentiating conditions [6]. Furthermore, when grown in 3D matrigel culture and subjected to differentiating media DFCI-2, the stem/progenitor cells are preferentially induced into luminal differentiation [25]. Notably, when we subjected $\mathrm{K} 5^{+} / \mathrm{K} 19^{-}$and $\mathrm{K}^{+} / \mathrm{K} 19^{+}$cells expressing triple oncogene combinations to differentiation using in-vitro 3D matrigel culture, we observed an increased CD49f+ (marker for stem cell) fraction ( $97 \%$ vs. $86 \%$ for $\mathrm{K}^{+} / \mathrm{K}^{-} 9^{-}$and $96 \%$ vs. $92 \%$ for $\mathrm{K}^{+} / \mathrm{K} 19^{+}$) and decrease in $\mathrm{MUC} 1+($ marker for luminal differentiation) fraction $(0.4 \%, 0.1 \%$ vs. $0.9 \%$ for $\mathrm{K}^{+} / \mathrm{K} 19^{-}$and $0.5 \%, 0.2 \%$ vs. $1.2 \%$ for $\mathrm{K}^{+} / \mathrm{K} 19^{+}$) in transformed lines vs. their controls (Figure 2A, 2B). These results indicate that oncogene-mediated transformation of mammary stem/progenitor cells reduces their ability to differentiate. Next, we assessed the ability of oncogenetransformed vs. vector control mammary stem/progenitor cell lines to form tumorspheres in ultra-low attachment plates, a commonly used assay to determine cancer stem cell self-renewal abilities [26-29]. Vector expressing cells showed formation of small spheres $(<200 \mu \mathrm{m})$ and were not counted (Figure 2C). Notably, cells expressing the triple combinations of oncogenes exhibited a significant increase in number of tumorsphere ( $>200 \mu \mathrm{m}$ in size) formed (Figure 2C, 2D). Both the transformed $\mathrm{K}^{+} / \mathrm{K} 9^{-}$ or $\mathrm{K}^{+} / \mathrm{K} 19^{+}$cells formed secondary tumorspheres upon re-plating (Supplementary Figure S1A) and the efficiency for tertiary tumorsphere formation was substantially enriched for cells over-expressing oncogene combination mRas/mp53/wtEGFR (Supplementary Figure S1B) demonstrating increased self-renewal capabilities of these transformed cell lines. Taken together, these results demonstrate an increase in stem cell property of triple oncogene transformed derivatives.

\section{Oncogene-transformed $\mathrm{K5}^{+} / \mathrm{K}^{-} 9^{-}$and $\mathrm{K5}^{+} / \mathrm{K}^{+} 9^{+}$ cells produce mixed tumors in NSG mice}

Given the in vitro capabilities of both cell types to exhibit anchorage independence and enhanced 
A

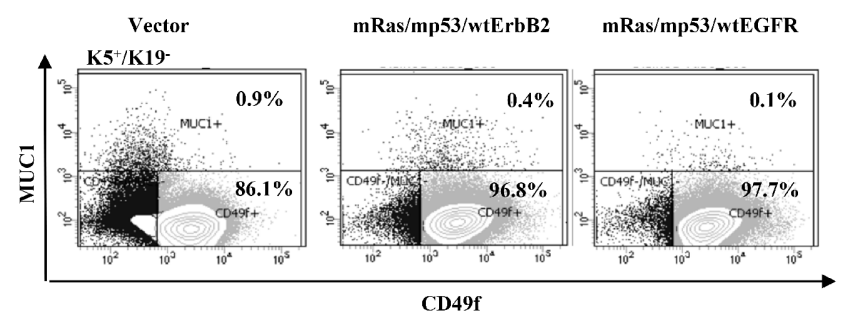

C

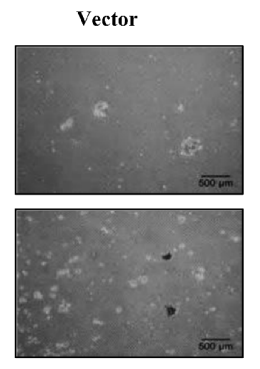

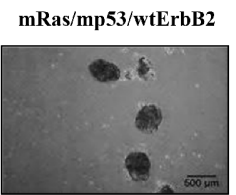

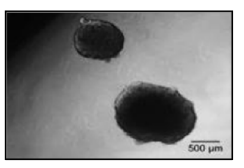

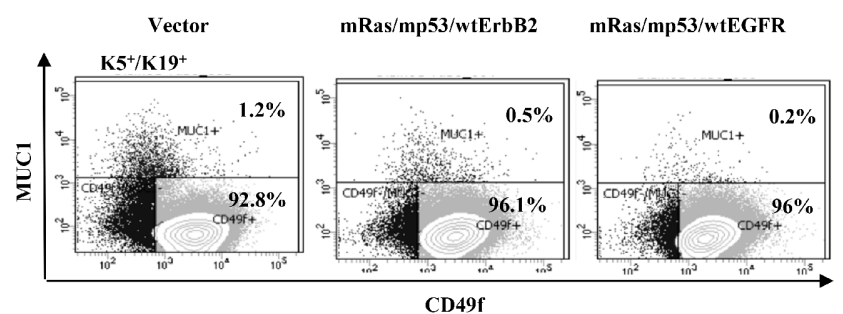

D

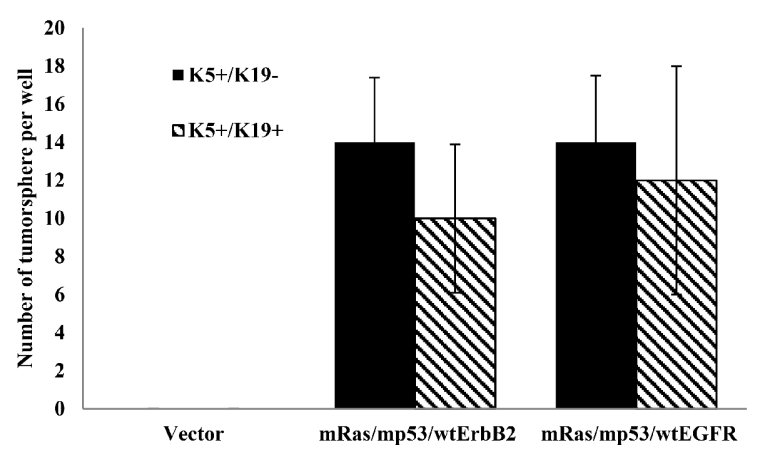

Figure 2: In-vitro self-renewal and differentiation of transformed $\mathrm{K5}^{+} / \mathrm{K}^{-} 9^{-}$or $\mathrm{K5}^{+} / \mathrm{K19}^{+}$. (A) and (B). Control or transformed $\mathrm{K} 5^{+} / \mathrm{K} 19^{-}$(A) or $\mathrm{K}^{+} / \mathrm{K} 19^{+}$(B) cells were grown in DFCI-2 (differentiation) medium in Matrigel. Acini were trypsinized and stained with PE-Cy5 conjugated anti-CD49f and FITC conjugated anti-MUC1 and subjected to FACS analysis. (C) Representative images (magnification $4 \mathrm{X}$ ) of tumorspheres from $\mathrm{K}^{+} / \mathrm{K} 9^{-}$and $\mathrm{K}^{+} / \mathrm{K} 19^{+}$cells with vector or triple oncogene combinations are shown. (D) For tumorsphere-formation assay indicated cell lines were cultured in low-attachment plates in MEGM media for 3 weeks. Spheres $\geq 200 \mu \mathrm{m}$ were quantified. Mean $+/-$ SD of a representative experiment done in 6 replicates is shown.

tumorsphere formation when transformed (Figure 1B, 1C and Figure 2D), we assessed their ability to form tumors upon orthotopic implantation in the mammary glands of immunocompromised NSG mice, as a proof of full oncogenic transformation. Triple (mRas/mp53/wtErbB2 or mRas/mp53/wtEGFR) oncogene transformed $\mathrm{K}^{+} /$ $\mathrm{K} 19^{-}$and $\mathrm{K}^{+} / \mathrm{K} 19^{+}$cells were injected orthotopically in mice mammary glands. As expected, none of the mice implanted with control vector cells produced tumors while all the triple oncogene transformed $\mathrm{K}^{+} / \mathrm{K} 19^{-}$and $\mathrm{K} 5^{+} / \mathrm{K} 19^{+}$cells gave rise to tumors in mice. Histologically, tumors arising from triple oncogene combinations in $\mathrm{K} 5^{+} / \mathrm{K} 19^{-}$and $\mathrm{K} 5^{+} / \mathrm{K}_{1} 9^{+}$cells appeared distinct from each other. Tumors arising from transformed $\mathrm{K}^{+} / \mathrm{K} 19^{-}$ cells exhibited predominance of spindle-like tumor cell morphology while those arising from transformed $\mathrm{K}^{+} /$ $\mathrm{K} 19^{+}$cells resembled adenocarcinomas (Figure $3 \mathrm{~A}$ ). These differences in the tumor phenotype are consistent with previous findings that biological differences in cell types can give rise to distinct histological subtypes of tumors $[4,5]$. We further observed that all tumors exhibited intratumoral heterogeneity as seen by the expression of various markers including MUC1 (for luminal differentiation), K5 (for stem-progenitor/basal), vimentin (for stem-progenitor/ basal/myoepithelial), $\alpha$-SMA (for myoepithelial) and claudin4 (for claudin-low) (Figure 3B, 3D, Supplementary
Figure S2). K5 $5^{+} / \mathrm{K} 19^{-}$cells over-expressing wtErbB2 combination predominantly gave rise to tumors with high claudin-low (spindle like, $\alpha-\mathrm{SMA}^{+}$, vimentin ${ }^{+}$, claudin $4^{-}$) and less basal $\left(\mathrm{K}^{+}\right)$characteristics, whereas the same cells over-expressing wtEGFR combinations formed tumors with mixed basal, luminal and claudin-low phenotype (Figure 3A, 3B). Similarly tumors arising from $\mathrm{K}^{+} /$ $\mathrm{K} 19^{+}$cells over-expressing wtErbB2 combination showed more luminal and basal characteristics, whereas those derived by wtEGFR combination had both luminal and basal with some claudin-low components (Figure 3B, 3D, Supplementary Figure S2). To exclude the possibility of mouse mammary gland contribution, we used human specific vimentin antibody to confirm that the tumors were derived from the injected human cells. Vimentin antibody used here is highly specific for human cells as it neither stains mouse mammary gland (Figure 4A, 4B) nor does it detects vimentin protein in western blotting using mouse fibroblasts (Supplementary Figure S3). In order to confirm that the claudin-low component within the tumors with mixed phenotype was derived from the transformed human stem/progenitor cells, we performed double immunostaining of these tumors with human specific anti-vimentin together with anti- $\alpha$-SMA, anti-Ecadherin (Figure 3C, 3D) or anti-claudin4 (Supplementary Figure S2). All tumors from transformed $\mathrm{K} 5^{+} / \mathrm{K} 19^{-}$and 


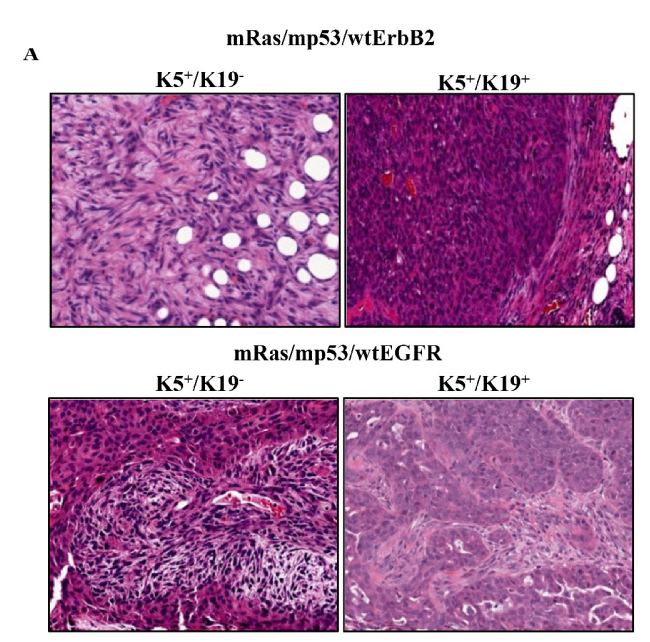

C

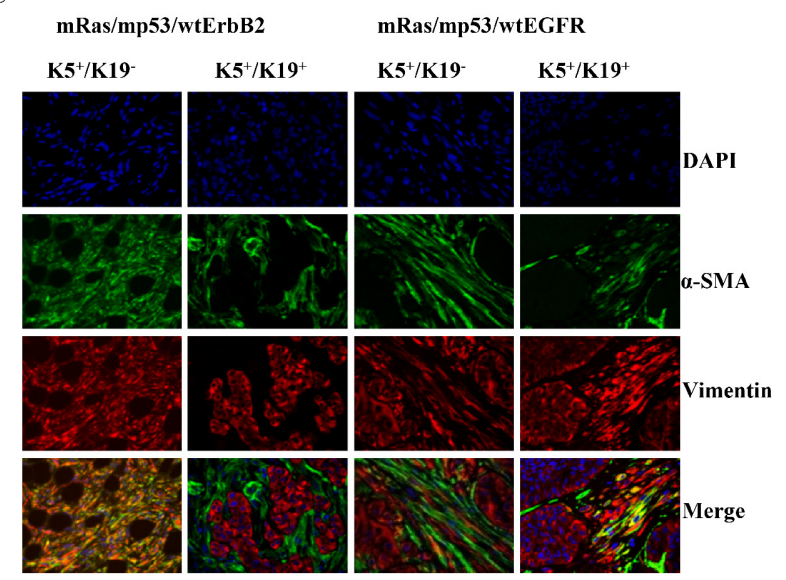

mRas/mp53/wtErbB2

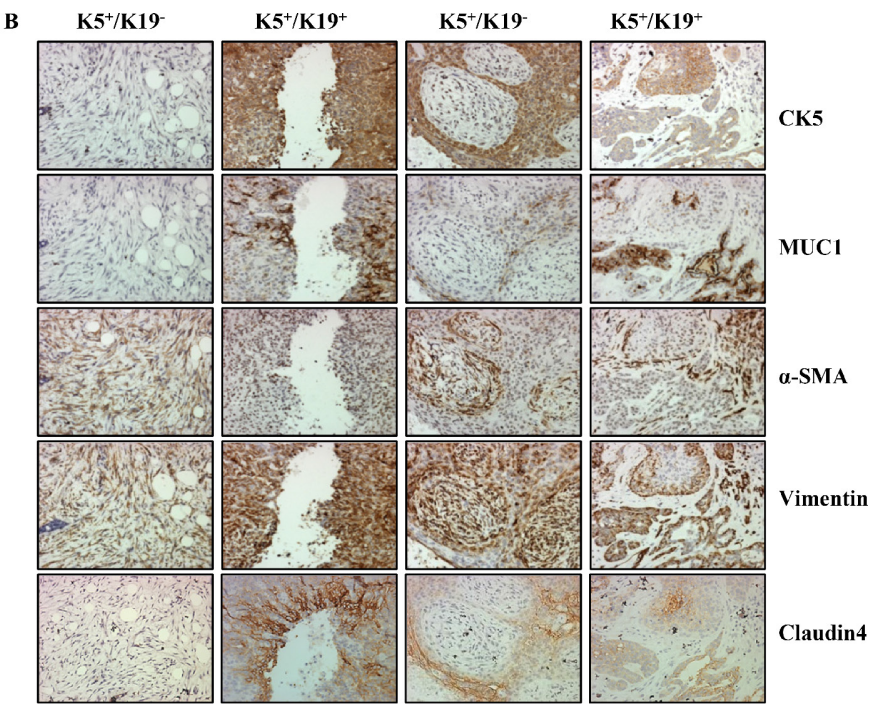

D mRas/mp53/wtErbB2 $\quad$ mRas/mp53/wtEGFR

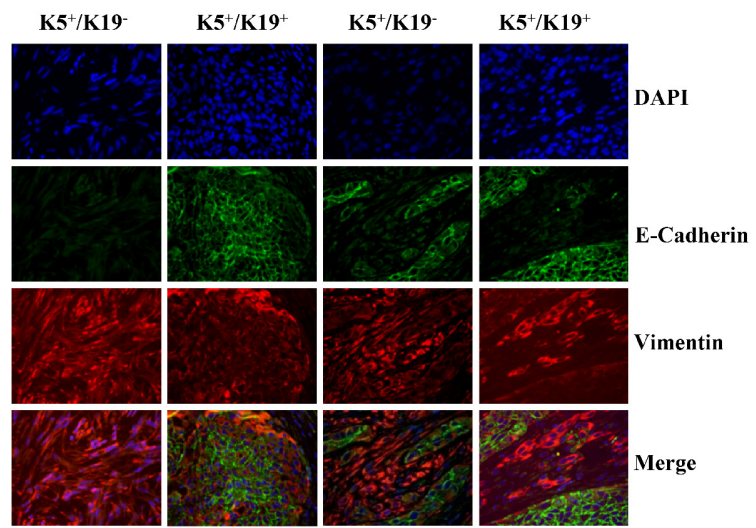

Figure 3: Transformed $\mathrm{K5}^{+} / \mathrm{K} 19^{-}$or $\mathrm{K5}^{+} / \mathrm{K} 19^{+}$cells give rise to distinct tumors. (A) Representative images of H\&E staining of tumor sections (magnification $20 \mathrm{X}$ ) from $\mathrm{K} 5^{+} / \mathrm{K} 19^{-}$and $\mathrm{K} 5^{+} / \mathrm{K} 19^{+}$cells over-expressing mRas/mp53/wtErbB2 (upper panel) or $\mathrm{mRas} /$ mp53/wtEGFR (Lower panel). (B) Images from different tumors at magnification 20X. Immunohistochemical staining of tumor sections with anti-CK5 (Basal/Stem), anti-MUC1 (Luminal), anti- $\alpha$ SMA (Myoepithelial) anti-vimentin (Stem/myoepithelial) and claudin4 (for claudin-low) antibodies. (C) Representative image of tumors from $\mathrm{K} 5^{+} / \mathrm{K} 19^{-}$orK $5^{+} / \mathrm{K}^{-} 9^{+}$cells double immunostained with anti- $\alpha \mathrm{SMA}$ (green) and anti-vimentin (red) show presence of claudin-low $\left(\mathrm{SMA}^{+} /\right.$vimentin $\left.{ }^{+}\right)$areas within different tumors. (D) Same tumor sections were double immunostained E-Cadherin (green) and vimentin (red) show presence of luminal like (E-Cadherin ${ }^{+}$) areas within different tumors. DAPI (blue) shows nucleus.

$\mathrm{K}^{+} / \mathrm{K} 19^{+}$stem/progenitor cells were ER-negative (data not shown) consistent with the ER-negative status of the parental normal stem/progenitor cells [6].

Interestingly, staining of tumor sections from mice injected with $\mathrm{K}^{+} / \mathrm{K} 19^{+}$cells over-expressing wtEGFR combination showed both infiltrating ductal carcinoma and well-formed ductal structures with varying degrees of hyperplasia. The hyperplastic structures had a well-defined outer $\alpha$-SMA-positive, vimentin positive (myoepithelial) and inner MUC1 positive (luminal) staining pattern (Figure 4A, 4B), indicative of the ability of human $\mathrm{K}^{+} /$ $\mathrm{K} 19^{+}$cells to differentiate into both myoepithelial and luminal cells in vivo.

\section{Both oncogene and cell type contribute to tumor development and progression in NSG mice}

Mice injected with cells over-expressing triple oncogene combinations developed tumors consistently (Tables 1, 2). Notably, tumors arising from $\mathrm{mRas} / \mathrm{mp} 53 /$ wtEGFR over-expressing $\mathrm{K}^{+} / \mathrm{K} 19^{-}$cell line had a statistically significant longer latency and lower tumor incidence than those arising from other cell lines tested (Figure 5A, Supplementary Table 2). The estimated time for $50 \%$ of mice to develop tumor was 20 weeks for $\mathrm{K}^{+} /$ K19- cell with mRas/mp53/wtEGFR and 11.75 weeks for $\mathrm{K}^{+} / \mathrm{K} 19^{-}$over-expressing $\mathrm{mRas} / \mathrm{mp} 53 / \mathrm{wtErbB} 2$ 

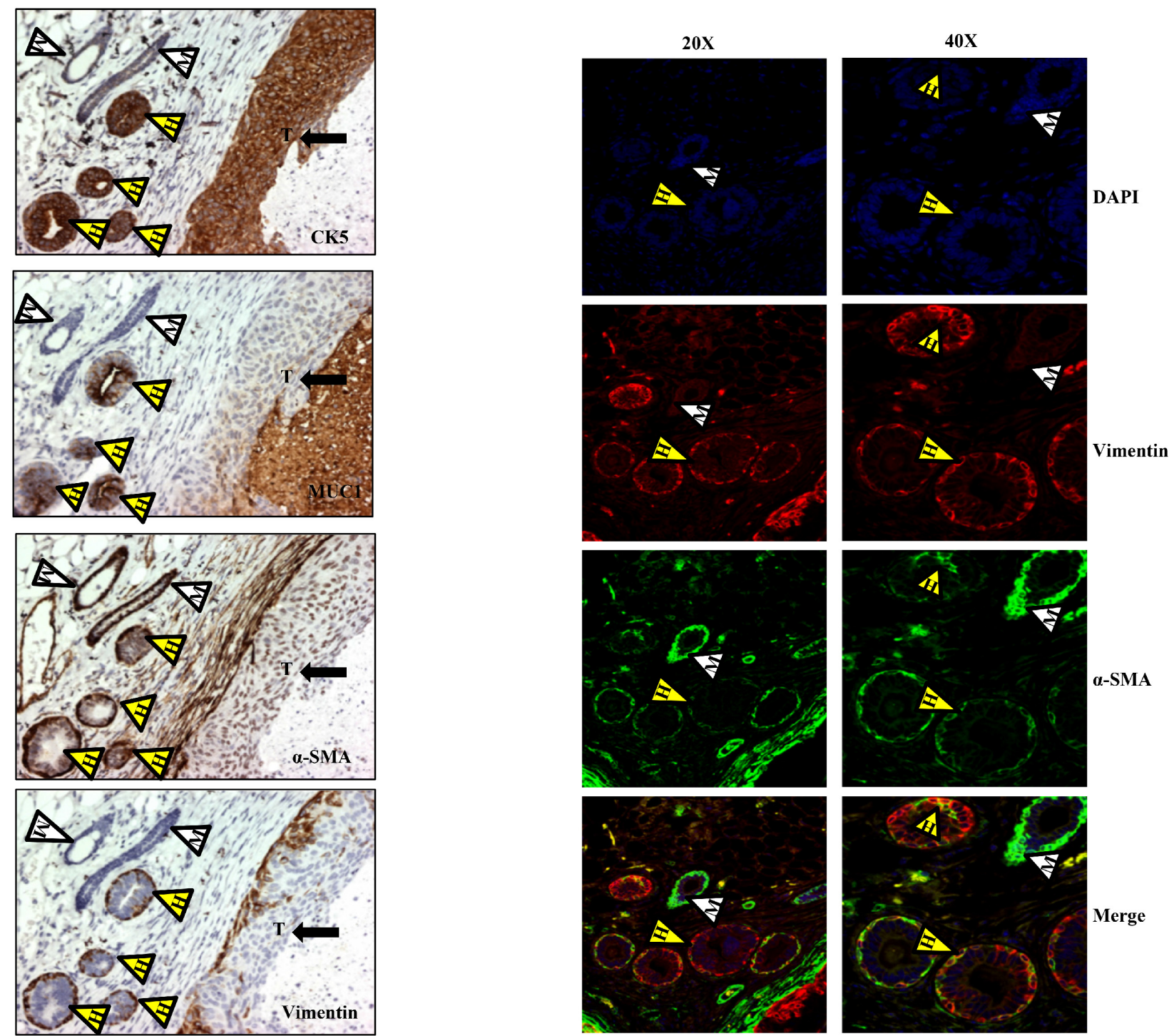

Figure 4: Transformed $\mathrm{K5}^{+} / \mathrm{K}^{-} 9^{-}$or $\mathrm{K5}^{+} / \mathrm{K} 19^{+}$cells retain stem cell characteristics in-vivo. (A) Immunostaining with lineage specific markers of tumors and mammary duct like structures with varying degree of hyperplasia originating from $\mathrm{K} 5^{+} / \mathrm{K} 19^{+}$cells over-expressing mRas/mp53/wtEGFR. Yellow arrowheads with $\mathrm{H}$ indicate human mammary ductal structures, white arrowheads with $\mathrm{M}$ indicate mouse mammary ducts and arrow with $\mathrm{T}$ shows tumor. (B) Immunofluorescence staining of the same tumor section with antivimentin (red), anti- $\alpha$ SMA (green) antibodies at magnifications 20X (left panel) and 40X (right panel). White arrowhead indicate mouse ductal structure, yellow arrowheads indicate co-expression in human ductal structures.

(Figure 5A, Supplementary Table 2). Despite the longer primary tumor latency wtEGFR combination had a higher lung metastasis incidence (Table 3, Figure 5B, 5C, Supplementary Table 3) as compared to wtErbB2 in $\mathrm{K}^{+} /$ $\mathrm{K} 19^{-}$cell line and unique liver metastasis (Figure 5E, Table 3, Supplementary Table 4). These results support the conclusion that different oncogenes can drive distinct oncogenic and metastatic potential in same cell type. On the other hand, we observed $\mathrm{K}^{+} / \mathrm{K}_{1} 9^{+}$cell line overexpressing $\mathrm{mRas} / \mathrm{mp} 53 / \mathrm{wtEGFR}$ had a low primary tumor latency as compared to $\mathrm{K} 5^{+} / \mathrm{K} 19^{-}$with same oncogene combination (Figure 5A, Tables 1, 2, Supplementary
Table 2) and high tumor incidence (Supplementary Table 5) as compared to all other cell lines tested. More significantly, $\mathrm{K}^{+} / \mathrm{K} 19^{+}$cell line over-expressing either mRas/mp53/wtErbB2 or mRas/mp53/wtEGFR had statistically significant lower lung metastasis latency (Figure 5B, Supplementary Table 6) as compared to $\mathrm{K}^{+} /$ $\mathrm{K} 19^{-}$with $\mathrm{mRas} / \mathrm{mp} 53 / \mathrm{wtErbB} 2$, higher lung metastasis incidence (Table 3, Supplementary Table 3 ) and bigger metastatic tumors (Figure 5D) as compared to $\mathrm{K}^{+} / \mathrm{K} 19^{-}$ cells over-expressing either of the oncogene combinations, indicating that the nature of cell type also affects the tumor and metastasis formation. 
A

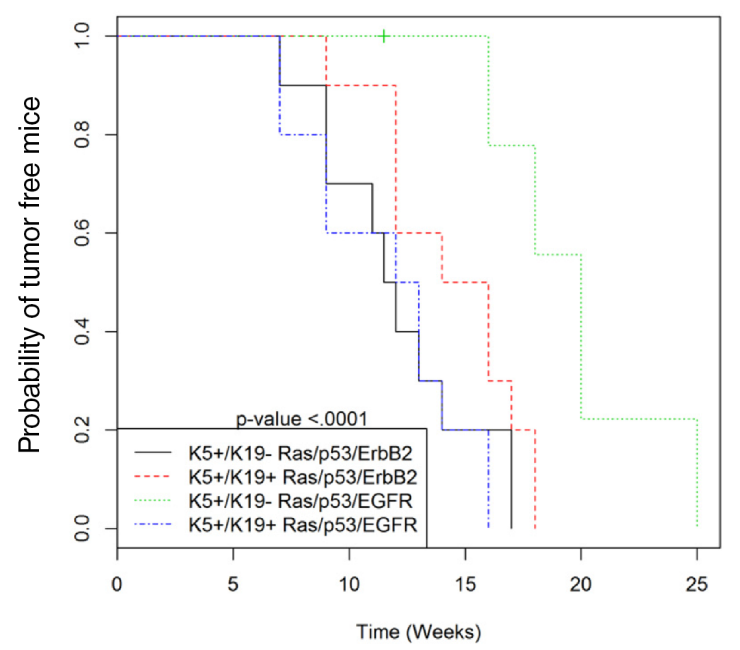

B

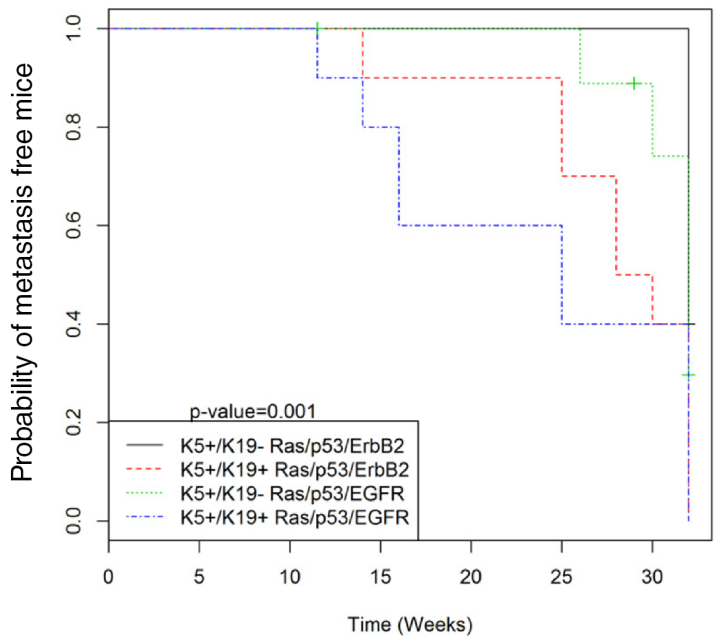

C

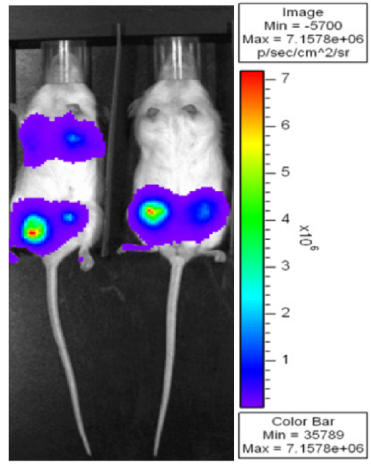

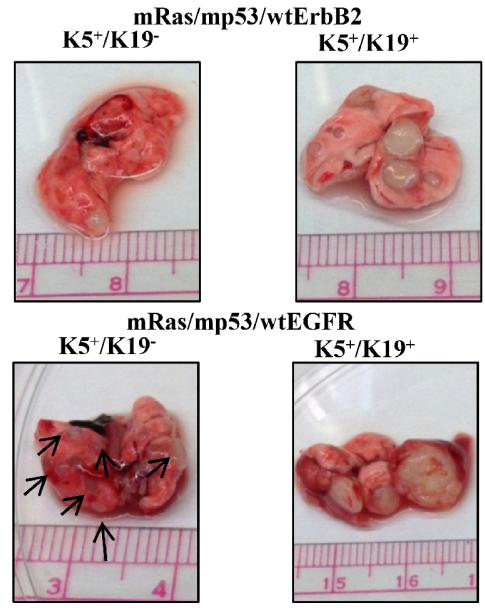

$\mathbf{E}$

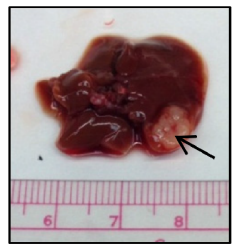

Figure 5: In-vivo tumor and metastasis formation from transformed $\mathrm{K5}^{+} / \mathrm{K19}^{-}$or $\mathrm{K5}^{+} / \mathrm{K}^{+} 9^{+}$cells. (A) Kaplan-Meier plot for probability of no tumor in mice injected with $\mathrm{K} 5^{+} / \mathrm{K} 19^{-}$and $\mathrm{K} 5^{+} / \mathrm{K} 19^{+}$cells over-expressing $\mathrm{mRas} / \mathrm{mp} 53 / \mathrm{wtErbB} 2 \mathrm{or} \mathrm{mRas} / \mathrm{mp} 53 /$ wtEGFR from the second experiment. (B) Kaplan-Meier plot for probability of no metastasis in above mentioned mice. (C) Representative image of mice with or without lung metastasis as shown by IVIS luciferase imaging. (D) Representative image of lung metastatic lesions formed by different cell types with either mRas/mp53/wtErbB2 (upper panel) or mRas/mp53/wtEGFR (Lower panel). (E) Representative image of liver metastasis as seen in mice injected with $\mathrm{K} 5^{+} / \mathrm{K} 19^{-}$cells over-expressing mRas/mp53/wtEGFR.

\section{TABLE 1: Tumor latency for $\mathrm{K5}^{+} / \mathrm{K} 19^{-}$and $\mathrm{K5}^{+} / \mathrm{K} 19^{+}$stem/progenitor cells with different combination.}

\begin{tabular}{|c|c|c|}
\hline Cell Line & $\begin{array}{c}\text { Tumor Onset (Time first tumor } \\
\text { appeared) }\end{array}$ & $\begin{array}{l}\text { No. of mice that formed tumors } \\
\text { (by } 24 \text { weeks) }\end{array}$ \\
\hline $\mathrm{K}^{+} / \mathrm{K} 19^{-} \mathrm{mRas} / \mathrm{mp} 53 / \mathrm{wtErbB} 2$ & 12 weeks & $4 / 4$ \\
\hline $\mathrm{K}^{+} / \mathrm{K} 19^{+} \mathrm{mRas} / \mathrm{mp} 53 / \mathrm{wtErbB} 2$ & 9 weeks & $4 / 4$ \\
\hline $\mathrm{K}^{+} / \mathrm{K} 19^{-} \mathrm{mRas} / \mathrm{mp} 53 / \mathrm{wtEGFR}$ & 24 weeks & $2 / 4$ \\
\hline $\mathrm{K}^{+} / \mathrm{K} 19^{+} \mathrm{mRas} / \mathrm{mp} 53 / \mathrm{wtEGFR}$ & 12 weeks & $4 / 4$ \\
\hline
\end{tabular}


TABLE 2: Tumor latency for $\mathrm{K5}^{+} / \mathrm{K}^{-} 9^{-}$and $\mathrm{K5}^{+} / \mathrm{K}^{+}$stem/progenitor cells with different combination.

\begin{tabular}{|c|c|c|c|}
\hline Cell Line & $\begin{array}{l}\text { Tumor Onset (Time first } \\
\text { tumor appeared) }\end{array}$ & $\begin{array}{l}\text { No. of mice that formed } \\
\text { tumors (by } 16 \text { weeks) }\end{array}$ & $\begin{array}{l}\text { No. of mice that formed } \\
\text { tumors (by } 16 \text { weeks) }\end{array}$ \\
\hline $\mathrm{K}^{+} / \mathrm{K} 19^{-} \mathrm{mRas} / \mathrm{mp} 53 / \mathrm{wtErbB} 2$ & 7 weeks & $10 / 10$ & $10 / 10$ \\
\hline $\mathrm{K}^{+} / \mathrm{K} 19^{+} \mathrm{mRas} / \mathrm{mp} 53 / \mathrm{wtErbB} 2$ & 9 weeks & $8 / 10$ & $10 / 10$ \\
\hline $\mathrm{K}^{+} / \mathrm{K} 19^{-} \mathrm{mRas} / \mathrm{mp} 53 / \mathrm{wtEGFR}$ & 16 weeks & $2 / 7$ & $7 / 7$ \\
\hline $\mathrm{K}^{+} / \mathrm{K}_{19} 9^{+} \mathrm{mRas} / \mathrm{mp} 53 / \mathrm{wtEGFR}$ & 7 weeks & $10 / 10$ & $10 / 10$ \\
\hline
\end{tabular}

TABLE 3: Metastasis observed with $\mathrm{K5}^{+} / \mathrm{K}^{-} 9^{-}$and $\mathrm{K5}^{+} / \mathrm{K}^{-} 9^{+}$stem/progenitor cells with different combination.

\begin{tabular}{l|c|c|c|}
\hline \multicolumn{1}{l}{ Cell Line } & $\begin{array}{c}\text { Metastasis first } \\
\text { appeared in mice }\end{array}$ & $\begin{array}{c}\text { No. of mice that formed } \\
\text { lung metastasis } \\
\text { by 32 weeks }\end{array}$ & $\begin{array}{c}\text { No. of mice that formed } \\
\text { liver metastasis } \\
\text { by 32 weeks }\end{array}$ \\
\hline $\mathrm{K} 5^{+} / \mathrm{K} 19^{-} \mathrm{mRas} / \mathrm{mp} 53 / \mathrm{wtErbB} 2$ & $31^{\text {st }}$ week & $6 / 10$ & $0 / 10$ \\
\hline $\mathrm{K} 5^{+} / \mathrm{K} 19^{+} \mathrm{mRas} / \mathrm{mp} 53 / \mathrm{wtErbB} 2$ & $25^{\text {th }}$ week & $10 / 10$ & $0 / 10$ \\
\hline $\mathrm{K} 5^{+} / \mathrm{K} 19^{-} \mathrm{mRas} / \mathrm{mp} 53 / \mathrm{wtEGFR}$ & $26^{\text {th }}$ week & $5 / 7$ & $2 / 7$ \\
\hline $\mathrm{K} 5^{+} / \mathrm{K} 19^{+} \mathrm{mRas} / \mathrm{mp} 53 / \mathrm{wtEGFR}$ & $11^{\text {th }}$ week & $10 / 10$ & $0 / 10$ \\
\hline
\end{tabular}

\section{DISCUSSION}

Diversity in breast tumors is multifactorial. Classification of tumors in to various subtypes emphasizes the important role of genetic mutation/overexpression in characterizing a tumor $[2,17,30]$. Besides, the type of cell in which a particular genetic event occurs is another important factor that may determine the phenotype of tumors $[4,5]$. While it is likely that tumor heterogeneity is of multifactorial origin, there is now wider acceptance of the idea that breast cancers exhibit a stem cell hierarchy [31-33].Thus, one aspect of cellular diversity in tumors is thought to reflect the relative contributions to tumor mass of cells representing various points in the stem cell program. However, experimental support for the relative importance of cell types from which tumors arise versus the oncogenic events themselves has been difficult as suitable cellular models have not been available. Here, we have transformed immortal human mammary stem/ progenitor cell lines with breast cancer-relevant cellular oncogenes to address these issues. Our analyses show that both the cell of origin as well as makeup of oncogenic events are important factors that shape the phenotype, oncogenicity as well as the metastatic behavior of a particular tumor.

We utilized two unique, well characterized normal human mammary stem/progenitor cell lines originating from a single donor that exhibit stable differences in keratin 19 expression as well as other genes (Microarray accession no. GSE22580, Supplementary Table 1) and are, designated as $\mathrm{K}^{+} / \mathrm{K} 19^{-}$and $\mathrm{K} 5^{+} / \mathrm{K} 19^{+}$. These cells can be propagated in culture as they have been rendered immortal with hTERT [6]. The cells remain in an undifferentiated state when grown in DFCI-1 medium but can be predictably induced to differentiate into myoepithelial and luminal lineages when cultured in differentiating media, thereby demonstrating their bi-potent nature [6]. Although majority of breast cancers are $\mathrm{K} 19^{+}$the mechanistic insights of this observation has not been addressed much in the literature. A correlative study suggested $\mathrm{K} 19^{+}$breast cancers exhibit poor prognosis [10]. Further studies have demonstrated, K19+ CTCs in breast cancer patients are associated with poor disease-free survival $[11,13]$. Additionally, treatment with trastuzumab can eliminate chemotherapy resistant K19 positive CTCs and can lead to reduction in disease recurrence and increased disease-free survival, suggesting K19 positive CTCs are associated with poor disease outcome [34]. Another study demonstrated that presence of CTCs with $\mathrm{K}_{19}{ }^{+}$expression during tamoxifen treatment is associated with increased risk of disease relapse [12]. Taken together, these studies underscore the importance of studying $\mathrm{K}_{1} 9^{+}$transformed breast cell lines.

Selection of transforming genes was based on a combination of relevance to human breast cancer and experimental ease. Choice of mp53, wtErbB2 or wtEGFR reflects a plethora of evidence that demonstrates a prevalent role of these in the pathogenesis of human breast cancers $[14,15,17,18]$. For example EGFR is overexpressed in basal subtype [35], ErbB2 is 
overexpressed in ErbB2+ subtype [18] while p53 is known to be frequently mutated in most breast cancer subtypes [17]. While selection of mutant Ras oncogene was based on evidence from a number of investigators, that mutant active Ras functions as a potent collaborator in full transformation of human mammary epithelial cells in in vitro, as well as in mouse mammary orthotopic tumorigenesis models [4, 5, 16, 36]. Notably, although the frequency of Ras mutations is low in breast cancer (about 5\% of total breast cancer cases) [17], activation of Ras pathway is frequently seen in breast tumors and in several breast cancer cell lines $[17,37,38]$. In addition to overexpression of upstream receptor tyrosine kinases EGFR and ErbB2 that are well known to activate Ras pathway as part of the oncogenic signaling program $[37,38]$, recent evidence has identified other oncogenic events that can activate the Ras pathway in breast cancer, including recurrent mutations in MAP3K1 [17, 39, 40] and mutations of RASAL2, a RasGAP gene that functions as negative regulator of Ras [41].

When we overexpressed defined combination of three oncogenes we observed an efficient anchorage independent growth in soft agar assays (Figure 1B, 1C). Consistent with the in vitro transformation (assessed by their ability to be anchorage independent) cells with triple oncogene combinations gave rise to tumors when orthotopically-implanted into mammary glands of immunocompromised mice. Significant differences in the onset of primary tumors and lung metastasis was observed when comparing different cell lines and different oncogene combination (Tables 1, 2, 3 Supplementary Tables 2, 3, 4, $5,6) . \mathrm{K} 5^{+} / \mathrm{K} 19^{+}$cells had a higher susceptibility towards transformation (Figure 1B) and had an early onset of primary tumors as well as lung metastasis as compared to $\mathrm{K} 5^{+} / \mathrm{K} 19^{-}$(Tables 1, 2, 3, Figure 5, Supplementary Tables 2, 6) suggesting that overall these $\mathrm{K}_{1} 9^{+}$stem/ progenitors are more prone to transformation. This may be the likely reason why more than $90 \%$ of human breast tumors are K19 positive $[8,9]$. This indicates that the cell type in which tumor initiates plays an important role in development and progression of tumor. In addition we found that, presence of EGFR instead of ErbB2 in the triple oncogene combination potentially drives an early lung metastasis and give unique liver metastasis from same cellular precursor i.e $\mathrm{K}^{+} / \mathrm{K} 19^{-}$(Table 3, Supplementary Table 4) suggesting the significant effect of an oncogene on pathogenicity of tumor. Most of the basal like breast tumors express or over-express EGFR and have a high propensity for metastasis. There are clinical reports that have shown an up-regulated EGFR expression in both primary and metastatic tumors [42, 43]. However the exact mechanism by which EGFR function in promoting metastasis is not very well understood. Besides the tumor latency and metastasis progression we also observed cell type dependent effect on primary tumor histology (Figure 3A). Together these data support the idea that both oncogenes and cell type in which oncogenesis was initiated contribute to key tumor traits, such as latency and incidence.

The mammary stem/progenitor cell lines utilized here are endowed with self-renewal and bipotent differentiation capabilities [6], allowing us to assess the impact of oncogenic transformation on their ability to self-renew and give rise to differentiated progeny. We present evidence that introduction of oncogenes into these stem/progenitor cell lines enhances their selfrenewal capability as assayed using tumorsphere assays (Figure 2D, Supplementary Figure S1) and reduces their differentiation potential (Figure 2A, 2B). It is likely that these traits are important in the tumorigenic phenotype as we observe these only upon oncogene overexpression. This is consistent with previous findings using in vivo mammary tumorigenesis models that tumor cells with loss of p53 function or overexpression of ErbB2 exhibit increased self-renewal [19], and that activated Ras or over-expression of EGFR inhibit normal mammary gland differentiation [20, 24].

Tumors in mice implanted with oncogenetransformed $\mathrm{K}^{+} / \mathrm{K} 19^{+}$or $\mathrm{K} 5^{+} / \mathrm{K} 19^{-}$cell lines exhibited substantial cellular heterogeneity with respect to the components of luminal, basal and/or claudin-low like cells, which were assessed by the expression of luminal and myoepithelial cell specific markers. Oncogenetransformed derivatives of $\mathrm{K} 5^{+} / \mathrm{K} 19^{+}$cells predominantly give luminal adenocarcinoma phenotype, whereas tumors arising from transformed $\mathrm{K} 5^{+} / \mathrm{K} 19^{-}$cell type produced more metaplastic carcinomas (Figure 3). Thus, our results clearly show that differences in cell of origin can substantially influence the tumor phenotype, consistent with previous reports where primary human mammary epithelial cells propagated in different culture conditions were used for transformation [4].

In conclusion, using a unique set of stem/progenitor hMECs, we demonstrate that both the cell type in which oncogenic events are initiated and the nature of oncogenic events contribute to breast cancer histology, onset and incidence of primary and metastatic tumor. These unique cellular models should be highly useful to further explore the mechanisms that contribute to cellular heterogeneity in breast cancer as well as other important traits linked to cancer stem cells such as therapy resistance and poor survival.

\section{MATERIALS AND METHODS}

Cell lines and retroviral/lentiviral infection. Mutant p53 ${ }^{\mathrm{R} 249 \mathrm{~S}}$ (mp53) in pLENTI-6 (purchased from Addgene) along with Invitrogen packaging vector (ViraPowerTM Lentiviral Packaging MIX) were transfected into 293FT packaging cells. Lentiviral supernatants were collected after overnight incubation in fresh DMEM media. TSA54 packaging cells were 
transfected with retroviral constructs, mutant H-Ras Q61L (mRas) in pBABE-hygro, wild type ErbB2 (wtErbB2) or wild type EGFR (wtEGFR) in pMSCV-puro vector or pMSCV GFP-luciferase vector (kind gift from Dr. Rakesh Singh, UNMC), together with PIK plasmid for packaging, and viral supernatants were collected (as mentioned above for lentiviral). $\mathrm{K}^{+} / \mathrm{K} 19^{-}$and $\mathrm{K}^{+} / \mathrm{K} 19^{+}$stem/progenitor cell lines [6] were infected with viral supernatants to generate cell lines with different gene combinations followed by their selection in DFCI-1 medium [44, 45] containing hygromycin $(15 \mathrm{ul} / \mathrm{ml})$ (for mutant H-Ras), blasticidine $(15 \mathrm{ul} / \mathrm{ml})$ (for mutant $\mathrm{p} 53)$, puromycin (0.5 ul/ml) (for wild type ErbB2 or EGFR).

Antibodies. The following antibodies were used for western blotting, immunofluorescence, flow-cytometry and immunohistochemistry (IHC): Rabbit anti-human ErbB2 (sc-284), mouse anti-human p53 (DO-1) (sc126), mouse anti-human $\alpha$-smooth muscle actin (SMA) (sc-32251), mouse anti-human vimentin (sc-6260) were from Santa Cruz Biotechnology. Mouse anti-human Ras (610001), mouse anti-human EGFR (610016), mouse anti-human MUC1 (550486), rat anti-human CD49f (555734), FITC conjugated anti-CD24 (555427), PE-Cy5 conjugated anti- CD49f (551129), PE-conjugated antiCD44 (555479), FITC conjugated anti-CD227 (MUC1559774) and Alexa-488 conjugated E-Cadherin (560061) were from BD Bioscience. Mouse anti-claudin4 (329400) was from Invitrogen. Rabbit anti-human vimentin (clone SP20, RM-9120-S0) was from Thermo Scientific. Rabbit anti-human K5 (PRB-160P) was from Covance.

Anchorage-independence growth assays. 40,000 cells suspended in DFCI-1 medium containing $0.3 \%$ agarose were seeded in the top layer of each well of 6-well plates containing $0.6 \%$ agarose as a bottom layer. Each cell line was plated in triplicates. Colonies $(>60$ cells) were counted after 3 weeks after crystal violet staining.

In vitro tumorsphere formation assays. 40, 000 cells were plated per $2 \mathrm{ml}$ in ultra-low attachment 6 well plates (Corning) in mammary epithelial growth medium (MEGM), as described previously by Dontu et al [27]. Each cell line had 6 replicates. Cells were fed with fresh medium on alternate days. Tumorspheres were counted under the microscope after 3 weeks of plating.

In vitro differentiation assays. Protocol used for matrigel assay has been described previously [7, 25]. Briefly, 1 million cells suspended in DFCI-2 [44, 45] medium containing $2 \%$ matrigel were plated on P-100 dish coated with $100 \%$ reconstituted basement membrane (matrigel from BD Biosciences). After 12 days (alternate day feeding), matrigel was dissolved using dispase enzyme (BD Biosciences) at $37^{\circ} \mathrm{C}$ for $1 \mathrm{hr}$, cells were counted and 1 million cells were stained with FITC conjugated antiCD227 (MUC1) and PE-Cy5 conjugated anti- CD49f and analyzed by FACS.
Xenograft transplantation assays for primary tumor formation. 6-8 weeks old immunodeficient NOD-SCID gamma (NSG) mice (purchased from Jackson laboratories) were injected with 1 million cells (not tagged with GFP-luciferase) in DFCI-1 medium mixed with matrigel in 1:1 proportion [4] in the fourth and ninth (contralateral) mammary glands. 4 mice were used for each combination. Tumor formation was assessed by palpation in the area of injection every week until 6 months. After six months, mice with or without tumors were sacrificed by $\mathrm{CO}_{2}$ inhalation followed by cervical dislocation. Tumors were excised, fixed with $10 \%$ neutral buffered formalin and processed to prepare paraffinembedded tumor blocks that were then sectioned for IHC.

Spontaneous metastasis formation assay. GFP-luciferase tagged tumor cells were injected in mammary glands of NSG mice. 10 mice were used for each combination. Mammary tumors formed after xenotransplantation of GFP-luciferase tagged tumor cells were surgically removed upon reaching $250 \mathrm{~mm}^{3}$ tumor size. Mice were routinely assessed for luciferase activity (peritoneal injection of $30 \mathrm{mg} / \mathrm{ml}$ luciferin substrate) by IVIS machine to detect any primary tumor and metastasis formation at different sites. Any subsequent tumors formed were also surgically removed and mice were assessed for metastasis formation for about 8 months.

Immunohistochemistry. Protocol for processing paraffin embedded tissue sections for immunostaining was essentially as described previously $[6,46]$. For IHC staining, tissue sections were incubated with primary antibodies (anti-K5, anti-MUC1, anti-vimentin, anti- $\alpha$ SMA or anti-claudin4) in a hydrated chamber, followed by incubation with HRP-tagged secondary IgG against the primary antibodies and subsequently processed for nuclear staining and mounting of tissues. For doubleimmunofluorescence staining tumor sections were processed similarly and blocked with $10 \%$ goat serum for $1 \mathrm{hr}$. These were then stained with rabbit anti-vimentin, alexa 488 conjugated anti-E-cadherin, mouse anti- $\alpha$-SMA or mouse anti-claudin 4 antibodies. Goat anti-rabbit alexa 594 and goat anti-mouse alexa 488 conjugated secondary antibodies (Invitrogen) were used for staining. The sections were mounted with anti-fade mounting media. Images were taken with fluorescence microscope (Zeiss axioplan 2 imaging microscope).

Statistical Analysis. Statistical analysis was performed to analyze the tumor and metastasis onset and incidence for each transfectant. Time to event outcomes (tumor latency and metastasis latency) were calculated using Kaplan-Meier plots and then compared among all four groups using log-rank tests. If the overall $p$-value was significant, pairwise comparisons for each pair cell types were made with Sidak's correction. Tumor onset rate at 16-week follow up, lung and liver metastasis rate at 32week follow up were compared using Fisher's exact tests. 


\section{ACKNOWLEDGEMENTS}

We thank all the members of Bands laboratories for their thoughtful discussion and suggestions throughout this work. This research is supported by the NIH grant CA96844 and CA144027 and Department of Defense grant W81XWH-11-1-0171 and W81XWH-14-1-0567 to V.B; the NIH grants CA87986, CA105489, CA99163, CA116552 and the NCI Core Support Grant to UNMCFred and Pamela Buffett Cancer Center to H.B.

\section{CONFLICTS OF INTEREST}

The authors declare no conflict of interest.

\section{Editorial note}

This paper has been accepted based in part on peerreview conducted by another journal and the authors' response and revisions as well as expedited peer-review in Oncotarget.

\section{REFERENCES}

1. Siegel R, Ma J, Zou Z, Jemal A. Cancer statistics, 2014. CA Cancer J Clin. 64:9-29.

2. Sorlie T, Perou CM, Tibshirani R, Aas T, Geisler S, Johnsen H, Hastie T, Eisen MB, van de Rijn M, Jeffrey SS, Thorsen T, Quist H, Matese JC, Brown PO, Botstein D, Lonning PE, et al. Gene expression patterns of breast carcinomas distinguish tumor subclasses with clinical implications. Proc Natl Acad Sci U S A. 2001; 98:10869-10874.

3. Prat A, Parker JS, Karginova O, Fan C, Livasy C, Herschkowitz JI, He X, Perou CM. Phenotypic and molecular characterization of the claudin-low intrinsic subtype of breast cancer. Breast Cancer Res. 2010; 12:R68.

4. Ince TA, Richardson AL, Bell GW, Saitoh M, Godar S, Karnoub AE, Iglehart JD, Weinberg RA. Transformation of different human breast epithelial cell types leads to distinct tumor phenotypes. Cancer Cell. 2007; 12:160-170.

5. Keller PJ, Arendt LM, Skibinski A, Logvinenko T, Klebba I, Dong S, Smith AE, Prat A, Perou CM, Gilmore H, Schnitt S, Naber SP, Garlick JA, Kuperwasser C. Defining the cellular precursors to human breast cancer. Proc Natl Acad Sci U S A. 2012; 109:2772-2777.

6. Zhao X, Malhotra GK, Lele SM, Lele MS, West WW, Eudy JD, Band H, Band V. Telomerase-immortalized human mammary stem/progenitor cells with ability to selfrenew and differentiate. Proc Natl Acad Sci U S A. 2010; 107:14146-14151.

7. Zhao X, Malhotra GK, Band H, Band V. Derivation of myoepithelial progenitor cells from bipotent mammary stem/progenitor cells. PLoS One. 2012; 7:e35338.

8. Petersen OW, Polyak K. Stem cells in the human breast. Cold Spring Harb Perspect Biol. 2010; 2:a003160.
9. Gudjonsson T, Villadsen R, Nielsen HL, Ronnov-Jessen L, Bissell MJ, Petersen OW. Isolation, immortalization, and characterization of a human breast epithelial cell line with stem cell properties. Genes Dev. 2002; 16:693-706.

10. Kabir NN, Ronnstrand L, Kazi JU. Keratin 19 expression correlates with poor prognosis in breast cancer. Mol Biol Rep. 2014; 41:7729-7735.

11. Ignatiadis $\mathrm{M}$, Xenidis $\mathrm{N}$, Perraki M, Apostolaki S, Politaki E, Kafousi M, Stathopoulos EN, Stathopoulou A, Lianidou E, Chlouverakis G, Sotiriou C, Georgoulias V, Mavroudis D. Different prognostic value of cytokeratin-19 mRNA positive circulating tumor cells according to estrogen receptor and HER2 status in early-stage breast cancer. J Clin Oncol. 2007; 25:5194-5202.

12. Xenidis N, Markos V, Apostolaki S, Perraki M, Pallis A, Sfakiotaki G, Papadatos-Pastos D, Kalmanti L, Kafousi M, Stathopoulos E, Kakolyris S, Mavroudis D, Georgoulias V. Clinical relevance of circulating CK-19 mRNA-positive cells detected during the adjuvant tamoxifen treatment in patients with early breast cancer. Ann Oncol. 2007; 18:1623-1631.

13. Xenidis $N$, Ignatiadis $M$, Apostolaki S, Perraki M, Kalbakis K, Agelaki S, Stathopoulos EN, Chlouverakis G, Lianidou E, Kakolyris S, Georgoulias V, Mavroudis D. Cytokeratin-19 mRNA-positive circulating tumor cells after adjuvant chemotherapy in patients with early breast cancer. J Clin Oncol. 2009; 27:2177-2184.

14. Sainsbury JR, Farndon JR, Needham GK, Malcolm AJ, Harris AL. Epidermal-growth-factor receptor status as predictor of early recurrence of and death from breast cancer. Lancet. 1987; 1:1398-1402.

15. Ro J, North SM, Gallick GE, Hortobagyi GN, Gutterman JU, Blick M. Amplified and overexpressed epidermal growth factor receptor gene in uncultured primary human breast carcinoma. Cancer Res. 1988; 48:161-164.

16. Elenbaas B, Spirio L, Koerner F, Fleming MD, Zimonjic DB, Donaher JL, Popescu NC, Hahn WC, Weinberg RA. Human breast cancer cells generated by oncogenic transformation of primary mammary epithelial cells. Genes Dev. 2001; 15:50-65.

17. Comprehensive molecular portraits of human breast tumours. Nature. 2012; 490:61-70.

18. Slamon DJ, Clark GM, Wong SG, Levin WJ, Ullrich A, McGuire WL. Human breast cancer: correlation of relapse and survival with amplification of the HER-2/neu oncogene. Science. 1987; 235:177-182.

19. Cicalese A, Bonizzi G, Pasi CE, Faretta M, Ronzoni S, Giulini B, Brisken C, Minucci S, Di Fiore PP, Pelicci PG. The tumor suppressor $\mathrm{p} 53$ regulates polarity of self-renewing divisions in mammary stem cells. Cell. 2009; 138:1083-1095.

20. Brandt R, Eisenbrandt R, Leenders F, Zschiesche W, Binas B, Juergensen C, Theuring F. Mammary gland specific hEGF receptor transgene expression induces neoplasia and inhibits differentiation. Oncogene. 2000; 19:2129-2137. 
21. Deugnier MA, Faraldo MM, Janji B, Rousselle P, Thiery JP, Glukhova MA. EGF controls the in vivo developmental potential of a mammary epithelial cell line possessing progenitor properties. J Cell Biol. 2002; 159:453-463.

22. Nair R, Roden DL, Teo WS, McFarland A, Junankar S, Ye S, Nguyen A, Yang J, Nikolic I, Hui M, Morey A, Shah J, Pfefferle AD, Usary J, Selinger C, Baker LA, et al. c-Myc and Her2 cooperate to drive a stem-like phenotype with poor prognosis in breast cancer. Oncogene. 2014; 33:3992-4002.

23. Jehn B, Costello E, Marti A, Keon N, Deane R, Li F, Friis RR, Burri PH, Martin F, Jaggi R. Overexpression of Mos, Ras, Src, and Fos inhibits mouse mammary epithelial cell differentiation. Mol Cell Biol. 1992; 12:3890-3902.

24. Cerrito MG, Galbaugh T, Wang W, Chopp T, Salomon D, Cutler ML. Dominant negative Ras enhances lactogenic hormone-induced differentiation by blocking activation of the Raf-Mek-Erk signal transduction pathway. J Cell Physiol. 2004; 201:244-258.

25. Zhao X, Malhotra GK, Band H, Band V. A block in lineage differentiation of immortal human mammary stem / progenitor cells by ectopically-expressed oncogenes. J Carcinog. 2011; 10:39.

26. Zhang M, Behbod F, Atkinson RL, Landis MD, Kittrell F, Edwards D, Medina D, Tsimelzon A, Hilsenbeck S, Green JE, Michalowska AM, Rosen JM. Identification of tumor-initiating cells in a p53-null mouse model of breast cancer. Cancer Res. 2008; 68:4674-4682.

27. Dontu G, Abdallah WM, Foley JM, Jackson KW, Clarke MF, Kawamura MJ, Wicha MS. In vitro propagation and transcriptional profiling of human mammary stem/ progenitor cells. Genes Dev. 2003; 17:1253-1270.

28. Charafe-Jauffret E, Ginestier C, Iovino F, Wicinski J, Cervera N, Finetti P, Hur MH, Diebel ME, Monville F, Dutcher J, Brown M, Viens P, Xerri L, Bertucci F, Stassi G, Dontu G, et al. Breast cancer cell lines contain functional cancer stem cells with metastatic capacity and a distinct molecular signature. Cancer Res. 2009; 69:1302-1313.

29. Mani SA, Guo W, Liao MJ, Eaton EN, Ayyanan A, Zhou AY, Brooks M, Reinhard F, Zhang CC, Shipitsin M, Campbell LL, Polyak K, Brisken C, Yang J, Weinberg RA. The epithelial-mesenchymal transition generates cells with properties of stem cells. Cell. 2008; 133:704-715.

30. Perou CM, Sorlie T, Eisen MB, van de Rijn M, Jeffrey SS, Rees CA, Pollack JR, Ross DT, Johnsen H, Akslen LA, Fluge O, Pergamenschikov A, Williams C, Zhu SX, Lonning PE, Borresen-Dale AL, et al. Molecular portraits of human breast tumours. Nature. 2000; 406:747-752.

31. Al-Hajj M, Wicha MS, Benito-Hernandez A, Morrison SJ, Clarke MF. Prospective identification of tumorigenic breast cancer cells. Proc Natl Acad Sci U S A. 2003; 100:3983-3988.
32. Reya T, Morrison SJ, Clarke MF, Weissman IL. Stem cells, cancer, and cancer stem cells. Nature. 2001; 414:105-111.

33. Liu H, Patel MR, Prescher JA, Patsialou A, Qian D, Lin J, Wen S, Chang YF, Bachmann MH, Shimono Y, Dalerba P, Adorno M, Lobo N, Bueno J, Dirbas FM, Goswami S, et al. Cancer stem cells from human breast tumors are involved in spontaneous metastases in orthotopic mouse models. Proc Natl Acad Sci U S A. 2010; 107:18115-18120.

34. Georgoulias V, Bozionelou V, Agelaki S, Perraki M, Apostolaki S, Kallergi G, Kalbakis K, Xyrafas A, Mavroudis D. Trastuzumab decreases the incidence of clinical relapses in patients with early breast cancer presenting chemotherapy-resistant CK-19mRNA-positive circulating tumor cells: results of a randomized phase II study. Ann Oncol. 2012; 23:1744-1750.

35. Livasy CA, Karaca G, Nanda R, Tretiakova MS, Olopade OI, Moore DT, Perou CM. Phenotypic evaluation of the basal-like subtype of invasive breast carcinoma. Mod Pathol. 2006; 19:264-271.

36. Kendall SD, Linardic CM, Adam SJ, Counter CM. A network of genetic events sufficient to convert normal human cells to a tumorigenic state. Cancer Res. 2005; 65:9824-9828.

37. Janes PW, Daly RJ, deFazio A, Sutherland RL. Activation of the Ras signalling pathway in human breast cancer cells overexpressing erbB-2. Oncogene. 1994; 9:3601-3608.

38. von Lintig FC, Dreilinger AD, Varki NM, Wallace AM, Casteel DE, Boss GR. Ras activation in human breast cancer. Breast Cancer Res Treat. 2000; 62:51-62.

39. Stephens PJ, Tarpey PS, Davies H, Van Loo P, Greenman C, Wedge DC, Nik-Zainal S, Martin S, Varela I, Bignell GR, Yates LR, Papaemmanuil E, Beare D, Butler A, Cheverton A, Gamble J, et al. The landscape of cancer genes and mutational processes in breast cancer. Nature. 2012; 486:400-404.

40. Banerji S, Cibulskis K, Rangel-Escareno C, Brown KK, Carter SL, Frederick AM, Lawrence MS, Sivachenko AY, Sougnez C, Zou L, Cortes ML, Fernandez-Lopez JC, Peng S, Ardlie KG, Auclair D, Bautista-Pina V, et al. Sequence analysis of mutations and translocations across breast cancer subtypes. Nature. 2012; 486:405-409.

41. McLaughlin SK, Olsen SN, Dake B, De Raedt T, Lim E, Bronson RT, Beroukhim R, Polyak K, Brown M, Kuperwasser C, Cichowski K. The RasGAP gene, RASAL2, is a tumor and metastasis suppressor. Cancer Cell. 2013; 24:365-378.

42. Hohensee I, Lamszus K, Riethdorf S, Meyer-Staeckling S, Glatzel M, Matschke J, Witzel I, Westphal M, Brandt B, Muller V, Pantel K, Wikman H. Frequent genetic alterations in EGFR- and HER2-driven pathways in breast cancer brain metastases. Am J Pathol. 2013; 183:83-95. 
43. Hicks DG, Short SM, Prescott NL, Tarr SM, Coleman KA, Yoder BJ, Crowe JP, Choueiri TK, Dawson AE, Budd GT, Tubbs RR, Casey G, Weil RJ. Breast cancers with brain metastases are more likely to be estrogen receptor negative, express the basal cytokeratin CK5/6, and overexpress HER2 or EGFR. Am J Surg Pathol. 2006; 30:1097-1104.

44. Band V, Sager R. Distinctive traits of normal and tumorderived human mammary epithelial cells expressed in a medium that supports long-term growth of both cell types. Proc Natl Acad Sci U S A. 1989; 86:1249-1253.
45. Band V, Zajchowski D, Kulesa V, Sager R. Human papilloma virus DNAs immortalize normal human mammary epithelial cells and reduce their growth factor requirements. Proc Natl Acad Sci U S A. 1990; 87:463-467.

46. Zhao X, Mirza S, Alshareeda A, Zhang Y, Gurumurthy CB, Bele A, Kim JH, Mohibi S, Goswami M, Lele SM, West W, Qiu F, Ellis IO, Rakha EA, Green AR, Band H, et al. Overexpression of a novel cell cycle regulator ecdysoneless in breast cancer: a marker of poor prognosis in HER2/ neu-overexpressing breast cancer patients. Breast Cancer Res Treat. 2010; 134:171-180. 